\title{
Microbial decomposition of large organic particles in the northwestern Mediterranean Sea: an experimental approach
}

\author{
Richard Sempérée $^{1, *}$, Séri C. Yoro ${ }^{1}$, France Van Wambeke ${ }^{1}$, Bruno Charrière ${ }^{2}$ \\ ${ }^{1}$ Laboratoire de Microbiologie Marine, CNRS/INSU, EP 2032, Case 907, Université de la Méditerranée, Campus de Luminy, \\ 13288 Marseille Cedex 9, France \\ ${ }^{2}$ Centre de Formation et de Recherche sur l'Environnement Marin, CNRS/INSU ERS 1745, 52 Avenue de Villeneuve, \\ 66860 Perpignan Cedex, France
}

\begin{abstract}
Sediment trap particles, as well as particulate organic material including particles larger than $10 \mu \mathrm{m}$ collected by in situ pumps (ISP) and fresh corpses of the gelatinous zooplankton species Thalia democratica, were collected in the northwestern Mediterranean Sea from April to July 1995, and incubated (after mixing with $0.2 \mu \mathrm{m}$ filtered seawater) under laboratory conditions with their own bacterial assemblages for 6 to $24 \mathrm{~d}$ in batches under oxic conditions and in the dark. Particulate (POC > $0.7 \mu \mathrm{m})$, dissolved (DOC $<0.7 \mu \mathrm{m})$ and colloidal $(0.02<\mathrm{COC}<0.7 \mu \mathrm{m})$ organic carbon contents, as well as bacterial abundance and production, were quantified over time. In all experiments, total organic carbon $(T O C=P O C+D O C)$ decrease covaried with an increase in bacterial abundance and production, bacteria being the main mediators of particle decomposition. We found that COC accounted for 19 to $31 \%$ of DOC immediately after particle dilution in $0.2 \mu \mathrm{m}$ filtered seawater, and always for less than $9 \%$ at the end of the experiments. As organic colloids comprised less than $7 \%$ of DOC in the $0.2 \mu \mathrm{m}$ filtered seawater used to dilute the particles, this result suggests that $\mathrm{COC}$ was mainly produced from particle decomposition. Assuming that bacterial populations were the sole decomposer of organic matter in the batches, the results gave bacterial growth efficiencies (BGE) in the range of 3 to $21 \%$, indicating that decomposition of these particles significantly produce $\mathrm{CO}_{2}$ through bacterial respiration. The results showed that bacteria degraded 16 to $87 \%$ of the initial amount of POC within the first $48 \mathrm{~h}$, whereas only 6 to $22 \%$ of POC was degraded in the second stages. Our data and modeling work based on such short incubation times suggest that salp bodies are composed of 1 labile and 1 refractory organic fraction, whereas both ISP-and trap particles are composed of 2 labile and 1 refractory organic fraction. A $1 \mathrm{G}$-model (for salp) and a $2 \mathrm{G}$-model for other particles was able to satisfactorily reproduce the data sets.
\end{abstract}

KEY WORDS: Mediterranean Sea $\cdot$ Bacteria $\cdot$ Particulate organic carbon

\section{INTRODUCTION}

The vectors of sinking particulate organic carbon (POC) are remains of plants and/or animals, faecal pellets, aggregates and exopolymer particles (Fowler \& Knauer 1986, Martin et al. 1987, Turley \& Lochte 1990, Asper et al. 1992, Passow \& Wassman 1994, Silver et al. 1998). During settling of this particulate material, rates

•E-mail: sempere@luminy.univ-mrs.fr of particle destruction through break-up, remineralization and dissolution are critical variables that determine the amount and the lability of the organic matter ultimately reaching the seafloor. Moreover, the chemical and biological transformations which occur during the descent of these particles in the water column may affect trophic interactions of aggregate consumers and associated organisms and, thus, modify the chemistry of the surrounding water (Goldman 1984, Shaffer 1996). The magnitude of the sinking flux and the depth at which it is remineralized, mainly by heterotrophic 
bacteria, are both important factors in the oceanic carbon cycle. It is essential to understand not only the processes but also the kinetics of particle disaggregation, as well as bacterial growth efficiencies (BGE). This latter parameter being an important tool for carbon budget on a global scale (Sempéré et al. in press).

It is presently well known that intense hydrolytic activity on aggregate POC by attached bacteria is an important pathway for production of dissolved organic carbon (DOC) which is mainly taken up by free-living bacteria (Cho \& Azam 1988, Herndl 1988, Karner \& Herndl 1992, Smith et al. 1992, 1995, Hoppe et al. 1993). However, the turnover rates of large particles and the extent to which DOC and other degradation products such as sub-micron particles or colloids are produced from these particles are far from being understood. Some attempts to assess POC fates including bacterial degradation, zooplankton grazing and physico-chemical disaggregations and turnover rates were made by measuring particulate flux along the water column by sediment traps (Lee \& Cronin 1982, Gardner et al. 1983, Walsh et al. 1988, Khripounoff \& Crassous 1994) and by measuring adsorption rates of radionucleides on particles (Moran \& Buesseler 1992, Van der Loeff et al. 1997).

The major biochemical processes and their degradation kinetics have also been examined in laboratory conditions. Such investigations showed that degradation of particulate material follows first-order kinetics and suggested that organic matter does not degrade.as a single pool (Berner 1980, Westrich \& Berner 1984, Henrich \& Doyle 1986, Harvey et al. 1995, Nguyen \& Harvey 1997). In addition, POC degradation as well as microbial parameters followed over time indicated that a part of organic matter is quickly and efficiently utilized by bacteria within the first days of the incubation period, whereas another part is slowly and less efficiently consumed in a later stage (Turley \& Lochte 1990). However, all these studies were performed with zooplankton, phytoplankton debris or axenic cultures of phytoplankton (Westrich \& Berner 1984, Henrich \& Doyle 1986, Turley \& Lochte 1990, Christaki \& Van Wambeke 1995, Harvey et al. 1995, Van Wambeke 1995, Nguyen \& Harvey 1997). To our knowledge, there is no report specifically dealing with the lability and the turnover rates of large particles $(>10 \mu \mathrm{m})$ collected by in situ pumps and drifting traps which are commonly used by marine scientists.

In this paper, we present a series of experiments performed with large organic particles collected in the water column in the northwestern Mediterranean Sea. The objectives of our study are (1) to measure the amount of POC degraded by bacteria and subsequently the amount of DOC and colloidal organic carbon $(\mathrm{COC})$ released by this process, (2) to determine
BGE on the pool of labile total organic carbon (TOC) and (3) to provide turnover rates for the labile fraction of TOC.

\section{MATERIALS AND METHODS}

Study area. Seawater and particle collection was carried out from April to July 1995 in the northwestern Mediterranean Sea in the framework of EMPS (April), Dyfamed (May), and Euromarge (July) projects (Fig. 1). Three stations were sampled, 1 located in the Gulf of Lions (Stn M3, $43^{\circ} 02^{\prime} \mathrm{N}, 05^{\circ} 12^{\prime} \mathrm{E}, 900 \mathrm{~m}$ depth) and 2 others located in the Ligurian Sea: Stn 1, 43. $50^{\prime}$ $\mathrm{N}, 7^{\circ} 8^{\prime} \mathrm{E}, 1300 \mathrm{~m}$ depth and $\operatorname{Stn} 2,43^{\circ} 25^{\prime} \mathrm{N}, 7^{\circ} 52^{\prime} \mathrm{E}$, $2300 \mathrm{~m}$ depth. Stns M3 and 1 were coastal stations under the influence of the northwestern Mediterranean Current (Christaki et al. 1996, Yoro et al. 1997) whereas Stn 2 was the permanent 'Dyfamed station', which can be considered as typical of the whole northwestern Mediterranean Sea (Copin-Montégut \& Avril 1993, Marty et al. 1994). Estimates of primary production in the northwestern Mediterranean basin averaged $78 \mathrm{~g} \mathrm{C} \mathrm{m}^{-2} \mathrm{yr}^{-1}$ (Minas 1970), whereas the sole new production was $18 \mathrm{~g} \mathrm{C} \mathrm{m}^{-2} \mathrm{yr}^{-1}$ (Minas et al. 1988). Transfer of organic material to deep layers takes place through diffusive processes and winter convection of DOC (18.4 $\mathrm{g} \mathrm{C} \mathrm{m}^{-2} \mathrm{yr}^{-1}$ Copin-Montégut \& Avril 1993) and from exportation of large sinking particles $(5 \mathrm{~g} \mathrm{C}$ $\mathrm{m}^{-2} \mathrm{yr}^{-1}$, Miquel et al. 1994).

Sampling. Particles were collected at 50 (Stn M3) and $200 \mathrm{~m}$ (Stn 1) depth by filtering 824 to $1000 \mathrm{l}$ of seawater with in situ pumps (Challenger Oceanics). equipped with $10 \mu \mathrm{m}$ pore-size filters (Nuclepore). Immediately after sampling, swimmers were discarded from the bulk of particle sets, then filters were maintained wet by adding a few $\mathrm{ml}$ of $0.2 \mu \mathrm{m}$ filtered seawater and stored in the dark until incubation experi-. ments in the land laboratory began (this time lapse never exceeded $6 \mathrm{~h}$ ). Particles were removed by injecting with a syringe ca $200 \mathrm{ml}$ of $0.2 \mu \mathrm{m}$ filtered seawater on the surface of the filters. The mixture was then transferred to a 21 glass bottle and stored in the dark, at in situ temperature. All glass bottles and vials used during this study were precombusted for $6 \mathrm{~h}$ at $450^{\circ} \mathrm{C}$ prior to utilization.

Large sinking particles were collected by a drifting Technicap-PPS5 sediment trap with a mouth of $1 \mathrm{~m}^{2}$ deployed without preservative at $200 \mathrm{~m}$ depth at $\operatorname{Stn} 2$ for $44 \mathrm{~h}$. After removal of the trap, swimmers were discarded, and a 21 glass bottle was filled with a part $(100 \mathrm{ml})$ of the 6 cups held by the rotary collector. The cup supernatant was also decanted and discarded to remove free-living bacteria and heterotrophic flagellates as much as possible. 


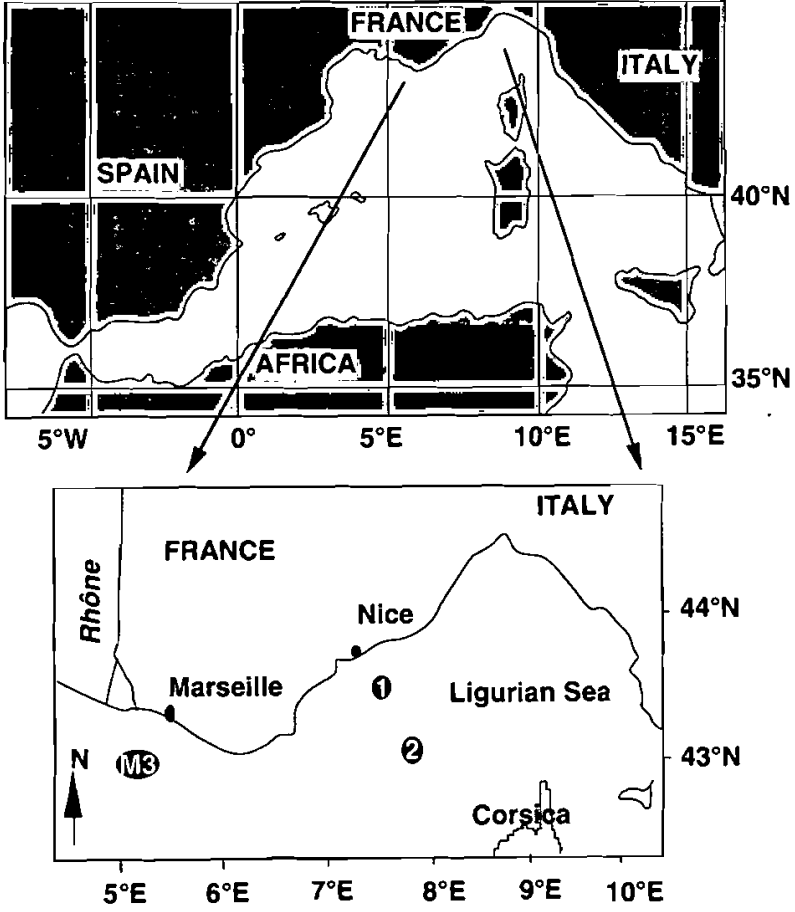

Fig. 1. Locations of the 3 stations studied (Stn M3: $43^{\circ} 10^{\prime}, 05^{\circ}$ $12^{\prime}$ E, $900 \mathrm{~m}$ depth; $\operatorname{Stn} 1: 43^{\circ} 50^{\prime} \mathrm{N}, 7^{\circ} 8^{\prime}$ E, $1300 \mathrm{~m}$ depth; Stn 2: $43^{\circ} 25^{\prime} \mathrm{N}, 7^{\circ} 52^{\prime} \mathrm{E}, 2300 \mathrm{~m}$ depth) during the Euromarge, EMPS and Dyfamed-Dynaproc cruises from April to July 1995 in the coastal northwestern Mediterranean Sea

The gelatinous zooplankton species Thalia democratica was collected using a zooplankton net at $10 \mathrm{~m}$ depth in the Bay of Villefranche-sur-mer. On board, these organisms were gently removed from the net, transferred into an aquarium and transported back to the laboratory (Villefranche-sur-mer Institute). Just before the laboratory experiment, they were rinsed .several times with $0.2 \mu \mathrm{m}$ filtered seawater and transferred to glass bottles. This experiment was conducted to study the bacterial response to inputs of fresh organic matter.

Incubation experiments. According to their abundance, the particles were diluted with 1 to 41 of $0.2 \mu \mathrm{m}$ filtered seawater collected at the same depth. Prior to filtration, the $0.2 \mu \mathrm{m}$ pore-size filters were flushed with large amounts of Milli- $Q$ water (2l) and 0.5 to 11 of seawater to minimize the potential organic contamination (Yoro et al. 1999). The solution including particles and $0.2 \mu \mathrm{m}$ filtered seawater was distributed in $500 \mathrm{ml}$ duplicate glass bottles with a headspace ratio of ca $150: 500 \mathrm{ml}$ to ensure oxic conditions throughout the incubation period. This was checked after the experiments by calculations taken from the TOC consumption during the whole incubations. The incubation bottles were closed with Teflon-lined screw caps and incu- bated in the dark at in situ temperature $\left(15\right.$ to $\left.18^{\circ} \mathrm{C}\right)$ for several days depending on bacterial growth, or decrease, and also on the quantity of material available for the incubation experiments. The incubation bottles were gently and regularly swirled upside-down to avoid particle deposition and to ensure oxic conditions. Each sub-sampling (each bottle corresponded to an incubation time) was performed by collecting aliquots for POC, DOC and COC as well as for bacterial production and/or abundance, after which the bottle was discarded. The standard deviation for the particle distribution, determined by measuring POC in various subsamples was about $8 \%$ at the start of the incubation. Experimental errors based on duplicate analyses for each experiment averaged $9 \%$ for TOC, $10 \%$ for bacterial abundance and $12 \%$ for bacterial production. Control experiments ( 3 sub-samples for ISP-50 m particle and 1 sub-sample for other stations) were performed by adding $\mathrm{HgCl}_{2}$ at the start of the experiment $\left(10 \mathrm{mg} \mathrm{l}^{-1}\right.$ final concentration) to batches containing particles and processed as the live experiments.

POC. For each bottle, $50 \mathrm{ml}$ was filtered through precombusted GF/F filters. The material collected on the GF/F filter (effective retention: $0.7 \mu \mathrm{m}$ ) was processed according to the method described by Tan \& Strain (1979), and assayed on a CS analyzer (CS 125-Leco) to measure POC. In preparation for POC analysis, the $\mathrm{GF} / \mathrm{F}$ filters were covered with a few ml of $2 \mathrm{~N} \mathrm{H}_{3} \mathrm{PO}_{4}$ and evaporated to dryness at $50^{\circ} \mathrm{C}$ for $12 \mathrm{~h}$ to remove inorganic carbon. The filters were then combusted, and the $\mathrm{CO}_{2}$ generated was measured by a non-dispersive infra-red cell, with a standard deviation of $2 \%$. POC values reported in this paper were calculated by subtracting bacterial biomass-C (determined from bacterial abundance and assuming that most of the bacteria were retained on the $G F / F$ filters during the filtration procedure) to the POC measured by Leco.

DOC and COC. The filtrate passing through the $\mathrm{GF} / \mathrm{F}$ filters was transferred into duplicate glass vials, poisoned with $50 \mu \mathrm{l}$ of $\mathrm{HgCl}_{2}$ (final concentration: $10 \mathrm{mg} \mathrm{l}^{-1}$ ) and closed with Teflon-lined screw caps and stored in the dark at room temperature. A few $\mathrm{ml}$ of the remaining sample in the bottle was filtered upon $0.02 \mu \mathrm{m}$ Anopore Whatman filters, previously cleaned with 1 to 21 of Milli-Q water to minimize the potential organic contamination of the filters. The filtrate obtained was considered as true DOC (RDOC < $0.02 \mu \mathrm{m}$ ) and analyzed for DOC. The carbon blank of the Anopore filter ( 4 to $8 \mu \mathrm{M} \mathrm{C}$, Yoro et al. 1999) was also measured and retrieved from the value of RDOC. COC was considered as the fraction between 0.02 (Anopore filter) and $0.7 \mu \mathrm{m}(\mathrm{GF} / \mathrm{F}$ filter), and thus, obtained by applying the following formula: $\mathrm{COC}=$ DOC - RDOC. TOC was calculated as the sum of POC and DOC. 
Samples for DOC analysis were measured by high temperature combustion on a Shimadzu TOC 5000 Analyzer. Details of this procedure have been previously described (Yoro et al. 1997, 1999). A 4-point calibration curve was performed daily with standards ( 83 to $332 \mu \mathrm{M} \mathrm{C}$ ) prepared by diluting a stock solution of potassium hydrogen phthalate in Milli-Q water. The instrument blank ranged from 6 to $9 \mu \mathrm{M} \mathrm{C}$.

Enumeration of bacteria. For each batch, a few $\mathrm{ml}$ of sample was preserved with $0.2 \mu \mathrm{m}$ filtered boraxbuffered formaldehyde ( $2 \%$ final concentration) for bacterial enumeration. Before slide preparation, samples were sonicated, diluted with $0.2 \mu \mathrm{m}$ filtered seawater (1:10) and sonicated again to separate attached bacteria from particles and ensure good distribution on the filter. Slides were prepared within $24 \mathrm{~h}$ following particle sampling in the batches to avoid underestimation of cell numbers due to possible losses during storage (Turley \& Hughes 1992). Bacteria were filtered onto $0.2 \mu \mathrm{m}$ pore-size Nuclepore filters and stained by DAPI (final concentration: $2.5 \mu \mathrm{g} \mathrm{ml}^{-1}$ ). Up to 30 fields were randomly counted with a Olympus BH2 epifluoresence microscope (Porter \& Feig 1980), the standard error between replicates ranged from 3 to $20 \%$. To compute the cell volume, we considered the rodshaped cells to be cylinders with a hemispherical cap. Bacterial biovolume measurements ranged from 0.033

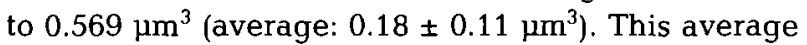
biovolume is slightly lower than that observed by Turley \& Lochte (1990): 0.2 to $0.3 \mu \mathrm{m}^{3}$ from biovolume measurements of bacteria incubated for $23 \mathrm{~d}$ with detritus of phyto- and zooplankton. Bacterial carbon biomass was estimated from abundance and biovolume using a power function calculated from Simon \& Azam (1989):

$$
y=90 V^{0.59}
$$

where $y$ is the amount of bacterial carbon per cell (fg $\mathrm{C}$ cell $^{-1}$ ) and $V$ the mean cell volume. The average conversion factor estimated by this method was $32 \mathrm{fg} \mathrm{C}$ bacterium $^{-1}$.

Bacterial production. Bacterial production was determined from rates of DNA synthesis as measured from rates of tritiated thymidine incorporation (Fuhrman \& Azam 1980). Two replicate samples (each $4 \mathrm{ml}$ ) and a formalin-killed control were incubated with 20.5 or $105 \mathrm{nM}$ (methyl- ${ }^{3} \mathrm{H}$ )-thymidine (specific activity: 44 to $65 \mathrm{Ci} \mathrm{mmol}^{-1}$ ), according to the abundance of particles. Previous studies performed with bacteria attached to large particles indicated that the incorporation of $\left({ }^{3} \mathrm{H}\right)$-thymidine was saturating at $20 \mathrm{nM}$ (Simon et al. 1990, Becquevort et al. 1998). Samples were incubated at in situ temperature and in the dark for a predetermined period ( 1 to $2 \mathrm{~h}$ ) that was in the linear phase of incorporation. Incubations were stopped with formalin ( $2 \%$ final concentration), samples were filtered through $0.2 \mu \mathrm{m}$ Nuclepore filters and then extracted with ice-cold $5 \%$ trichloroacetic acid. Bacterial production was estimated from $\left({ }^{3} \mathrm{H}\right)$-thymidine incorporation rates by applying the theoretical conversion factor of $2 \times 10^{18}$ cells mol $^{-1}$ (Ducklow \& Carlson 1992), which is also comparable to the empirical factors previously used in particle degradation experiments $(1.7$ and $2.6 \times 10^{18}$ cells $\mathrm{mol}^{-1}$; Simon et al. 1990 and Becquevort et al. 1998, respectively). We applied a cell-tocarbon conversion value of $32 \mathrm{fg} \mathrm{C} \mathrm{Cell}^{-1}$ as determined from bacterial biovolume measurements.

BGE. We determined BGE from TOC decreases and from the increases in bacterial biomass-C. Bacterial biomass was calculated either from the cell abundance or from thymidine-based bacterial production of bacteria over time, leading to the following formulae

$$
\begin{aligned}
\mathrm{BGE} & =(\triangle \mathrm{BB} / \triangle \mathrm{TOC}) \times 100 \\
\mathrm{BGE} & =(\mathrm{IBP} / \triangle \mathrm{TOC}) \times 100
\end{aligned}
$$

where IBP is integrated bacterial production cumulated over the successive interval periods and determined from rates of thymidine incorporation, $\triangle \mathrm{BB}$ is the difference of bacterial biomass between the initial time and the end of the first period of biodegradation, and $\triangle T O C$ is the amount of TOC utilized during the same time interval. Whatever the method used, bacterial respiration is deduced from the $B G E$ as follows:

$$
\% \text { respiration }=100-\mathrm{BGE}(\%)
$$

Kinetics of particle decay. The kinetics of TOC and POC decomposition can be described by the first-order (exponential) decay of 2 reactive organic matter fractions. Hence, we considered the 2 classes (labile and less labile) of both TOC and POC concentration of any constituent at a point in time $[G(t)]$ as the product of its original concentration $\left(G_{0}\right)$ and the first-order decay constant $(k)$ at that time as follows:

$$
G(t)=G_{0} \exp ^{(-k t)}
$$

We constructed a simple 2G-model in which each class (labile and less labile) is degraded with a firstorder rate constant. In this model, we assume that an organic fraction is not degraded during experimental time $\left(G_{\mathrm{NR}}\right)$. Based on the formulation of Westrich \& Berner (1984), we represent the TOC and POC data as a function of time by an equation of the form:

$$
G_{\mathrm{T}}(t)=G_{01}\left[\exp \left(-k_{1} t\right)\right]+G_{02}\left[\exp \left(-k_{2} t\right)\right]+G_{\mathrm{NR}}
$$

where $G_{\mathrm{T}}, G_{01}$ and $G_{02}$ are the total concentrations, the labile-class concentration and the less labile-class concentration of organic carbon (POC or TOC), respectively (see Table 3 ). $G_{\mathrm{NR}}$ was defined as the concentration of the non-reactive class of POC or TOC fraction during the incubation times. The rate $k_{1}$ was defined as 
Table 1. Net variations of the different pools of organic carbon $(\triangle T O C, \triangle P O C, \triangle D O C, \triangle C O C)$ expressed as percentages of the initial amount of organic carbon. $\Delta \%=100 \times$ (final concentration - initial concentration)/initial concentration. POC values were corrected for bacterial biomass assuming that most of the bacteria were retained on the GF/F filters used for filtration. ISP: particles larger than $10 \mu \mathrm{m}$ collected by in situ pumps. Control: batches poisoned with $\mathrm{HgCl}_{2}$. nd: not determined

\begin{tabular}{|lcccccrr|}
\hline Sample ID & $\begin{array}{c}\text { Experiment } \\
\text { duration }(\mathrm{d})\end{array}$ & $\begin{array}{c}\text { TOC init. } \\
(\mu \mathrm{M})\end{array}$ & $\begin{array}{c}\text { POC init. } \\
(\mu \mathrm{M})\end{array}$ & $\begin{array}{c}\Delta \text { TOC } \\
(\%)\end{array}$ & $\begin{array}{c}\Delta \text { POC } \\
(\%)\end{array}$ & $\begin{array}{c}\Delta \text { COC } \\
(\%)\end{array}$ & $\begin{array}{r}\Delta \text { DOC } \\
(\%)\end{array}$ \\
\hline ISP-50 m & 23 & 1113 & 906 & -57 & -68 & nd \\
ISP-50 m (control) & 23 & 860 & 750 & -8 & -30 & -17 \\
ISP-200 m & 8.3 & 181 & 81 & -17 & -34 & -81 & -4 \\
Trap particles & 9.9 & 365 & 261 & -31 & -50 & -50 & 18 \\
Salps & 5.7 & 794 & 683 & -82 & -93 & -100 \\
\hline
\end{tabular}

the first-order decay constant of the most reactive TOC or POC and $k_{2}$ the first-order decay constant of the less reactive $\mathrm{POC}$ or TOC and $t$ the time of decomposition.

\section{RESULTS}

The TOC concentrations (calculated as DOC+POC) in the batches were 2- to 10-fold the concentrations found in the water column. Attempts to balance the initial POC/TOC concentrations in the different incubation experiments were not successful because we did not have access to the POC analyzer when experiments were initiated immediately after sampling. Immediately after the particle dilution, DOC concentrations in the different types of batches ranged from 100 to $207 \mu \mathrm{M} \mathrm{C}$, which are higher than those found in the surrounding water ( 70 to $100 \mu \mathrm{M} \mathrm{C}$ ). Since the batches were made by mixing particles and $0.2 \mu \mathrm{m}$ filtered seawater, this indicates that some DOC is released from particles immediately after their dilution in the batches. The DOC increases were also observed in the control experiments, suggesting that the mechanism leading to this initial production of DOC from the particles is likely to be also abiotic. During the incubation time, TOC decreased by 6 to $9 \%$ of the initial concentration in the batch controls (Table 1, Figs. 2 to 5) whereas bacterial growth was negligible, indicating that biotic mechanisms play the main role in the TOC decreases observed during non-poisoned incubations. TOC decrease in batch controls might also be due to adsorption of POC or DOC on the bottle wall or to experimental error.

\section{Organic carbon consumption}

Following enclosure of non-poisoned particle solutions, we observed an initial sharp decrease of POC concentration, i.e. $524 \mu \mathrm{M} \mathrm{C}(52 \%$ of POC initial concentration) in $0.8 \mathrm{~d}$ for ISP-50 m (Fig. 2), $13 \mu \mathrm{M} \mathrm{C}$
$(16 \%)$ in $1 \mathrm{~d}$ for ISP-200 $\mathrm{m}$ (Fig. 3), $597 \mu \mathrm{M} \mathrm{C} \mathrm{(87 \% )} \mathrm{in}$ $1.9 \mathrm{~d}$ for salps (Fig. 4) and $81 \mu \mathrm{M} \mathrm{C}(31 \%)$ in $0.5 \mathrm{~d}$ for trap particles (Fig. 5), followed by a lower decline thereafter until the end of the incubation. By contrast, DOC concentrations showed little variation. Indeed, throughout the experiments, average DOC values in the experimental flasks were $219 \mu \mathrm{M} \mathrm{C}( \pm 15 \%)$ for ISP-50 m, $90 \mu \mathrm{M} \mathrm{C}( \pm 10 \%)$ for ISP- $200 \mathrm{~m}, 107 \mu \mathrm{M} \mathrm{C}$ $( \pm 8 \%)$ for salp and $99 \mu \mathrm{M} \mathrm{C}( \pm 8 \%)$ for trap particles. Basically, the highest decrease of the TOC (POC+ DOC) content was observed for cadavers of salps $(77 \%$

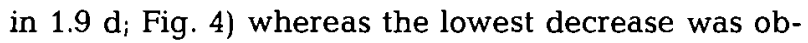
served for ISP-200 m particles (14\% in $1 \mathrm{~d}$ ) (Table 1 ,
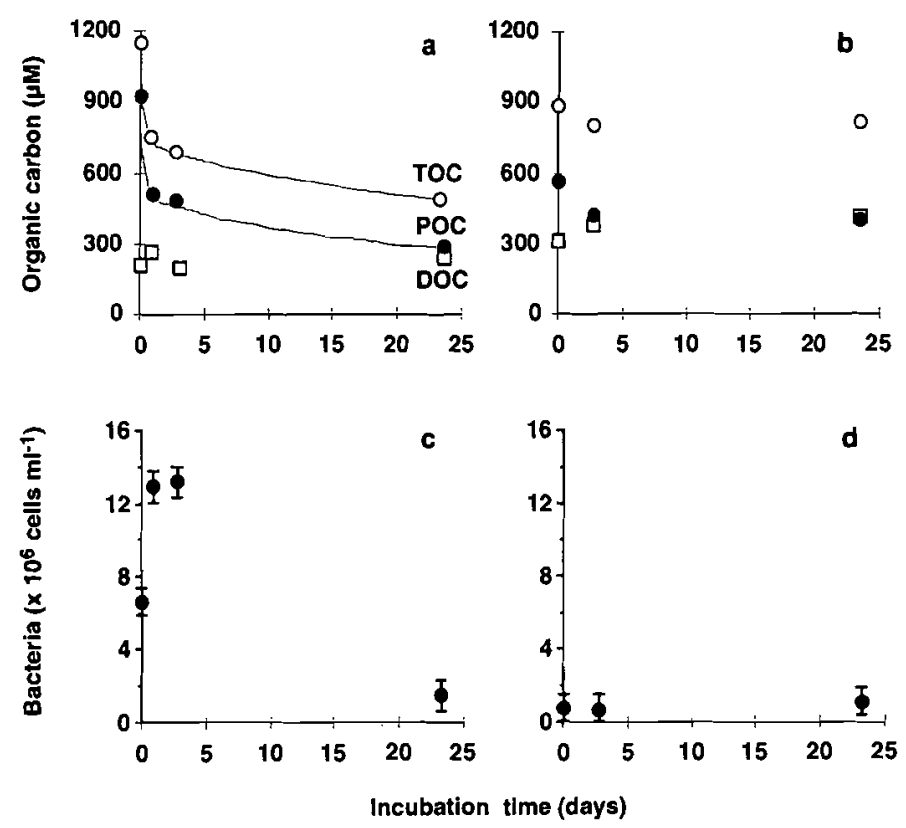

Fig. 2. Time-course responses of the different fractions of $(a, b)$ organic carbon and $(c, d)$ bacterial abundance from incubation experiments performed with ISP-50 m particles, i.e. material larger than $10 \mu \mathrm{m}$ collected on July 7,1995 , by in situ pumps at $50 \mathrm{~m}$ depth at Stn $\mathrm{M} 3$ in the Gulf of Lions: $(a, c)$ live incubation, (b,d) control (solution poisoned with $\mathrm{HgCI}_{2}$ ). Lines represent the $2 \mathrm{G}$-model concentrations for TOC and POC 


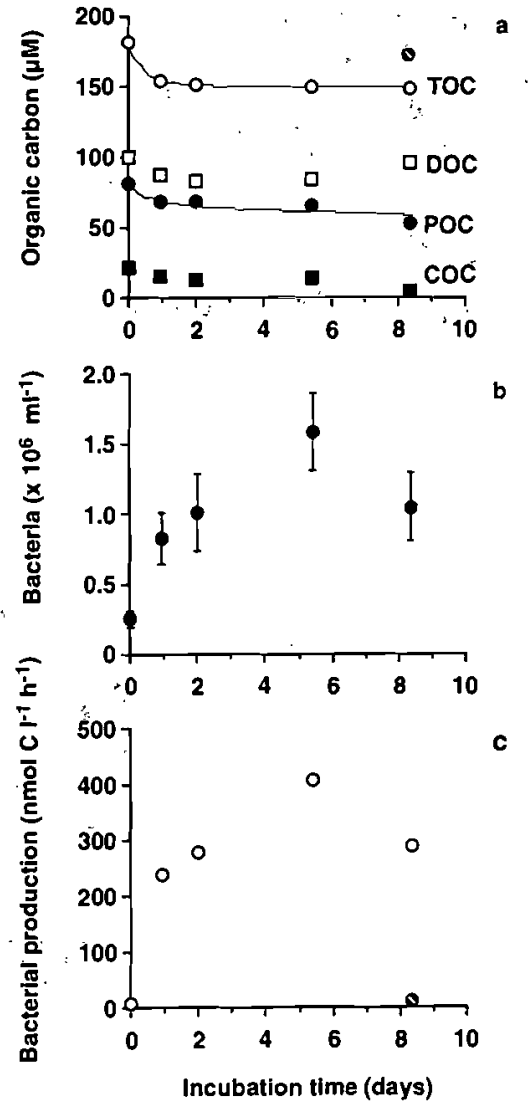

Fig. 3. Time-course responses of the different fractions of (a) organic carbon, (b) bacterial abundance and (c) production from incubation experiments performed with ISP- $200 \mathrm{~m}$ particles, i.e. material larger than $10 \mu \mathrm{m}$ collected on April 3, 1995 by in situ pumps at $205 \mathrm{~m}$ depth at $\operatorname{Stn} 1$ in the Ligurian Sea. Lines in (a) represent the 2G-model concentrations of TOC and POC. Dashed circles: poisoned controls

Fig. 3). TOC decreases for ISP-50 $\mathrm{m}$ particles and $200 \mathrm{~m}$ trap particles were $34 \%(0.8 \mathrm{~d})$ and $27 \%(0.5 \mathrm{~d})$; respectively. In the second stages of decomposition (after ca 1 to $2 \mathrm{~d}$ ) $18 \%$ of ISP-50 m particles were remineralized, whereas the TOC fraction remineralized in other batches was much lower ( 1 to $5 \%$, Table 1 ).

Concentrations of COC only measured in salp, ISP-200 m particle and trap-particle experiments accounted for 19 to $31 \%$ of DOC at the beginning and for less than $9 \%$ of DOC at the end of the experiments. By contrast, they accounted for less than $7 \%$ of the DOC pool in surrounding water, indicating that they were rapidly released by particles at the beginning of the incubation period. Interestingly, 70 to $80 \%$ of the DOC produced by the dilution of the particle stage $(t=0)$ was in colloidal state, indicating that the abiotic and/or biotic processes that took place immediately after the introduction of particles into the experimental flasks produced essentially DOC in the colloidal size range 0.02 to $0.7 \mu \mathrm{m}$.

\section{Bacterial abundance and production}

Accompanying the initial decrease of $\mathrm{TOC}_{\text {, we }}$ observed an increase of bacterial abundance and/or production (Figs. 2 to 5 ) in all experiments, indicating that activity of attached bacteria was essential to decrease TOC concentrations. It should be noticed that filtration of the seawater used to dilute the particles through $0.2 \mu \mathrm{m}$ pore-size filters excludes the free-living bacteria and their grazers. Thus, in the initial conditions, particles were present with their natural microbial communities.

In such a way, initial bacterial densities for salp, ISP$200 \mathrm{~m}$ and ISP $-50 \mathrm{~m}$ incubation bottles were ca 3.3, 2.5 and 1.1 times lower, respectively, than total counts found in seawater at the depth of collection (Bianchi et al. 1997). By contrast, an enhancement factor of 1.7 was obtained with trap particles. However, bacterial
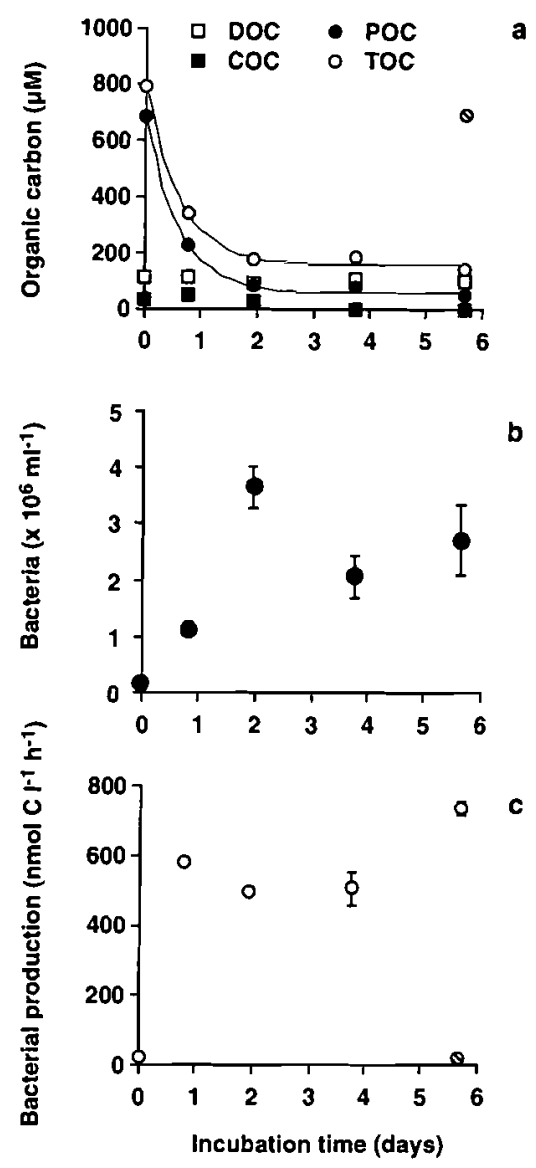

Fig. 4. Time-course responses of the different fractions of (a) organic carbon, (b) bacterial abundance and (c) production from incubation experiments performed with fresh bodies of salps collected at $10 \mathrm{~m}$ depth in April 4, 1995, in the Bay of Villefranche-sur-mer. Lines on (a) represent the 1G-model concentrations for TOC and POC. Dashed circles: poisoned controls 


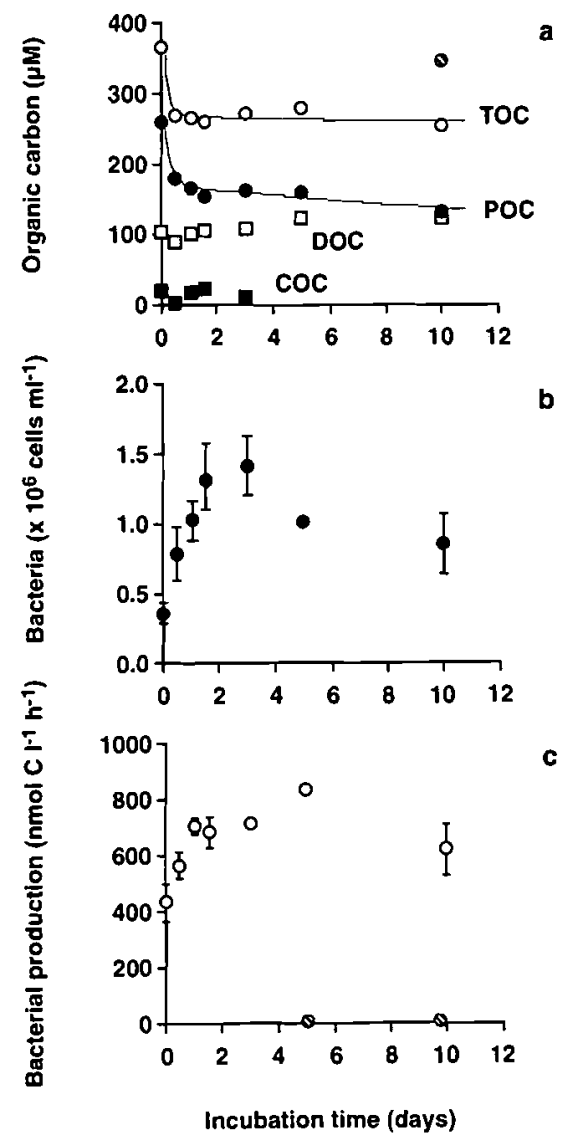

Fig. 5. Time-course responses of the different fractions of (a) organic carbon, (b) bacterial abundance and (c) production from incubation experiments performed with drifting trap particles deployed at $200 \mathrm{~m}$ depth at Stn 2 (DYFAMED station) and collected on June 1, 1995. Lines on (a) represent the 2G-model concentrations for TOC and POC. Dashed circles: poisoned controls

production rates in incubation bottles for ISP-200 m particles, salps and trap particles, were 17,22 and 2088 times higher than that found in the water column. It should be kept in mind that bacterial production and biomass are related to the total population including free-living and attached bacteria. Bacterial abundance at the beginning of the experiments ranged from 0.25

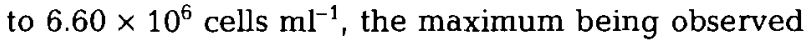
for ISP-50 m particles $\left(6.60 \times 10^{6}\right.$ cells ml $\left.{ }^{-1}\right)$. The values observed at the peak of abundances ranged from 1.41 to $13.9 \times 10^{6}$ cells $\mathrm{ml}^{-1}$. Bacterial densities in the batches increased by a factor of 5 to 10 during the first days of incubations. Bacterial production increased from 8.5 to $683 \mathrm{~nm} \mathrm{C} \mathrm{l}^{-1} \mathrm{~h}^{-1}$ during the same time interval (Figs. 3 to 5). The drastic decrease in bacterial abundance and production observed after 2 or $6 \mathrm{~d}$ of incubation could be due to the increase in bacterivores (heterotrophic flagellates) in the batches (Newell et al. 1981). In fact, random microscope transects checked on our slides did not show a significant number of heterotrophic flagellates at the beginning of the experiment but indicated that they were rather more abundant at the end of the experiment.

\section{Bacterial growth efficiency}

BGE (Table 2) determined from integrated bacterial production ( 3 to $31 \%$ ) were higher than those calculated from bacterial biomass ( 1 to $6 \%$ ), indicating that the use of bacterial abundance led to significant underestimation ( 3 to 10 times) of the BGE (Table 2). Even considering thymidine-based BGE, between 69 and $97 \%$ of the organic matter utilized by bacteria was respired. Surprisingly, BGE determined for salps (1 to $3 \%$, Table 2 ) were among the lowest values observed, suggesting that only a small part of the labile TOC utilized by bacteria contributed to bacterial biomass.

\section{Kinetics of particle decay}

Our results showed that TOC was rapidly turned over by bacteria during the first days ( $<2 \mathrm{~d}$ ) of the incubation period, and then slowly utilized during the following days (Figs. 2 to 5 ). This pattern suggests that at least 2 classes of TOC were being degraded with different mineralization rates: 1 rapidly degraded class (called labile) that causes the initial drop, and a more slowly degraded class of less labile TOC (hereafter called less labile). The so-called 'refractory fraction' $\left(G_{\mathrm{NR}}\right)$ is not degraded during the incubation time.

The measurements indicated that the time when rates changed suddenly occurred at $1.9 \mathrm{~d}$ for salps,

Table 2. Bacterial growth efficiencies (BGE \%) calculated from TOC depletion and bacterial biomass increase $(\triangle \mathrm{BB})$ or TOC depletion and integrated bacterial production (IBP) during the first period ( 2 to $3 \mathrm{~d}$ according to the experiments). IBP was calculated from the rates of thymidine incorporation assuming a conversion factor of $2 \times 10^{18}$ bacteria per mole of thymidine incorporated and $32 \mathrm{fg} C$ bacterium $^{-1}, \triangle \mathrm{BB}$ is the net increase of bacterial biomass determined from bacterial abundance assuming a conversion factor of $32 \mathrm{fg} \mathrm{C}$ bacterium ${ }^{-1}$ (see 'Materials and methods'). ISP: particles larger than $10 \mu \mathrm{m}$ collected by using in situ pumps. nd: not determined

\begin{tabular}{|lccc|}
\hline Sample ID & $\begin{array}{c}\text { Period } \\
\text { considered (d) }\end{array}$ & $\begin{array}{c}\text { BGE \% } \\
\Delta \mathrm{BB}\end{array}$ & $\begin{array}{c}\text { BGE \% } \\
\text { IBP }\end{array}$ \\
\hline ISP-50 m & $0-2.8$ & 1.4 & 3.3 \\
ISP-200 m & $0-2.0$ & 6.1 & 31 \\
Trap particles & $0-1.6$ & 2.1 & 21 \\
Salps & $0-1.9$ & 3.6 & nd \\
\hline
\end{tabular}


$0.5 \mathrm{~d}$ for trap particles, $1 \mathrm{~d}$ for ISP- $200 \mathrm{~m}$ and $0.8 \mathrm{~d}$ for ISP-50 m. Then, we initially determined $G_{01}$ as the concentrations of POC or TOC decomposed (or consumed) during these periods of time whereas the value of $G_{\mathrm{NR}}$ was initially calculated as the concentrations at the end of the experiments. In a first approach, the values of $G_{02}$ were taken as the difference between total measured initial carbon and the sum of $G_{01}$ and $G_{\mathrm{NR}}$. By substituting these results in Eq. (6) as initial values and then by using least-square minimization method (Solver function of Excel), we obtained the adjusted values of $k_{1}, k_{2}, G_{01}, G_{02}$ and $G_{\mathrm{NR}}$ for POC and TOC (Table 3 ). By contrast to the other decompositions, the best fit for salp decomposition (Fig. 4) was obtained for similar values of $k_{1}$ and $k_{2}$ indicating that the degradation (TOC and POC) can be approached by a $1 \mathrm{G}$-model $\left(k_{\mathrm{POC}}=1.65 \mathrm{~d}^{-1}\right.$, $G_{\mathrm{NRPOC}}=61 \mu \mathrm{M} \mathrm{C}_{i} k_{\mathrm{TOC}}=1.60 \mathrm{~d}^{-1}, G_{\mathrm{NRTOC}}=162 \mu \mathrm{M}$ C). For the other experiments (Figs. 2, $4 \&$ \&), the approximate values of $k_{1 \mathrm{TOC}}$ ranged from 2.16 (ISP$200 \mathrm{~m}$ ) to $6.14 \mathrm{~d}^{-1}$ (trap) whereas $k_{2 \text { Toc }}$ ranged from 0.007 (ISP-200 m) to 0.307 (trap) $\mathrm{d}^{-1}$. These data are in general agreement with those found for POC (Table 3). It should be noticed that POC degradation rates (Table 3) are not equivalent to those found for TOC, because the POC decomposition produces DOC which is not completely consumed by bacteria.

Table 3. Coefficients of the 2G-model (1G-model for salp experiment) as determined by the model adjustment to the data (least-square minimization, Newton method). $G_{01}$ : pool highly degradable (Iabile class), $G_{02}$ : pool slowly degradable (less labile class), $G_{\mathrm{NR}}$ : refractory pool. These 3 terms are expressed in percentage of the initial amounts of POC and TOC concentrations specified in Table 2. Rates $k_{1}$ and $k_{2}$ are the exponential decay rates determined by the model adjustment according to the equation $G_{\mathrm{T}}(t)=G_{01}\left[\exp \left(-k_{1} t\right)\right]+$ $G_{02}\left[\exp \left(-k_{2} t\right)\right]+G_{\mathrm{NR}}$. Errors estimated as percentages of the difference between observations and data calculated with the model are also given

\begin{tabular}{|cccccc|}
\hline $\begin{array}{l}\text { Organic } \\
\text { carbon }\end{array}$ & $\begin{array}{c}\text { Coeffi- } \\
\text { cients }\end{array}$ & ISP-50 m & ISP-200 m & $\begin{array}{c}200 \mathrm{~m} \\
\text { trap }\end{array}$ & Salps \\
\hline POC & $G_{01}(\%)$ & 45 & 16 & 35 & 84 \\
& $G_{02}(\%)$ & 33 & 16 & 35 & 7 \\
& $G_{\mathrm{NR}}(\%)$ & 22 & 68 & 30 & 9 \\
& $k_{1}\left(\mathrm{~d}^{-1}\right)$ & 3.20 & 1.93 & 3.93 & 1.65 \\
& $k_{2}\left(\mathrm{~d}^{-1}\right)$ & 0.058 & 0.13 & 0.045 & \\
& $\mathrm{CV}(\%)$ & 2.8 & 3.4 & 2.2 & 6.4 \\
& & & & & \\
TOC & $G_{01}(\%)$ & 35 & 17 & 27 & 74 \\
& $G_{02}(\%)$ & 32 & 17 & 2 & 6 \\
& $G_{\mathrm{NR}}(\%)$ & 34 & 66 & 71 & 20 \\
& $k_{1}\left(\mathrm{~d}^{-1}\right)$ & 3.16 & 2.16 & 6.13 & 1.60 \\
& $k_{2}\left(\mathrm{~d}^{-1}\right)$ & 0.058 & 0.0074 & 0.31 & \\
& $\mathrm{CV}(\%)$ & 0.1 & 0.05 & 2.1 & 4.2 \\
& & & & & \\
\hline
\end{tabular}

\section{DISCUSSION}

\section{Mechanisms of particle decomposition}

The small changes of DOC concentrations together with a high POC decrease observed over time for experiments indicate an intense biotic and/or abiotic DOC production followed by a rapid cycling of DOC in living batches during particle decomposition. Particle mineralization is likely due to an intense ectoenzymatic activity of attached bacteria which renders the particles soluble through macromolecular hydrolysis and produces dissolved organic compounds and small molecules which are subsequently taken up by attached and free-living bacteria (Karner \& Herndl 1992, Smith et al. 1992). It is also interesting to note that DOC quantitatively increased in the poisoned batches, despite the lack of bacterial development. This strongly suggests that particles also produce abiotic DOC. These results are consistent with the recognition that a significant fraction of DOC is continuously released from POC (Biddanda \& Pomeroy 1988, Williams 1990). Although they are not well quantified, the abiotic processes capable of aggregate destruction are numerous and could include physical breakdown (Karl et al. 1988, Wells \& Goldberg 1993), cell lyses and diffusion of solutes from the particles (Jumars et al. 1989).

Incubation experiments performed with fresh corpses of salps provided evidence for a rapid response of bacteria to inputs of labile material. Hard parts accounted for a small part in the salp bodies. Hence, decomposition of the animals induced rapidly dissolved organic compounds readily utilizable by bacteria such as carbohydrates and proteins. Indeed, more than $80 \%$ of the initial amount of salp-C was mineralized within $6 \mathrm{~d}$, which is significantly higher than the labile fraction found for trap (29\%), ISP-50 m (39\%) and ISP-200 $\mathrm{m}$ particles $(16 \%)$. The results indicated that at $200 \mathrm{~m}$, trap-TOC was more labile than ISP-TOC (see $\%$ of labile fraction, $G_{01}$, and $k_{1}$ ). Large aggregates are the main material deposited in the trap cups, whereas it is likely that particles collected with in situ pumps, even when equipped with $10 \mu \mathrm{m}$ pore-size, comprised a wider spectrum of size classes since small particles can adsorb on the filter surface because of the clogging of pores during pumping. Since the pore-size filter $(10 \mu \mathrm{m})$ is much higher than that of free-living bacteria $(0.2$ to $1 \mu \mathrm{m})$, attached bacteria are likely to be the main microbes present in the solution at the beginning of the experiment. Therefore, the material collected on the ISP filters probably includes smaller and older particles in addition to the $>10 \mu \mathrm{m}$ particles which lead to lower values of degradation rates. Moreover, trap particles comprise, in addition to other aggregates, faecal pellets which contain internal bac- 
teria coming from the gut of animals (Lawrence et al. 1993) able to enhance bacterial activities (Turley \& Mackie 1994). The labile fraction of ISP-50 m particles was higher than for ISP- $200 \mathrm{~m}$ particles, indicating that the more labile part of the particulate material was probably already degraded during the sedimentation between 50 and $200 \mathrm{~m}$.

\section{Colloid production}

High concentrations of sub-micron particles $(0.4$ to $1 \mu \mathrm{m})$ have been already observed in the euphotic layer in the Pacific Ocean (Koike et al. 1990, Yamasaki et al. 1998). In the Mediterranean Sea, we reported high concentrations of large colloids (>500 kD) in particle-rich environments such as the bottom nepheloid layer in the Gulf of Lions (Sempéré et al. 1994) or in the Krka estuary (Sempéré \& Cauwet 1995), suggesting that high concentrations of particles promote abiotic/ biotic production of large colloids. Ectoenzymatic activity of bacteria is one mechanism that might be responsible for sub-micron particle production during particle degradation (Smith et al. 1992). In the incubation bottles, release of metabolic waste in the colloidal size range (0.02 to $0.7 \mu \mathrm{m})$ by protozoans (Koike et al. 1990) cannot be precluded, although flagellates were found not to be abundant in the solutions. Small organic particles can also be generated during the physical or biological breakdown of large aggregates (McCave 1984, Karl et al. 1988, Wells \& Goldberg 1993). Unfortunately, COC were not measured in control experiments and, therefore, the intitial abiotic and biotic origin of colloids cannot be explained here.

\section{Efficiency of organic carbon utilization}

The results indicated that carbon-based BGE was always lower when calculated from cell counting than from bacterial production experiments. This phenomenon, already observed for dissolved organic matter biodegradation (Kirchman et al. 1991, Amon \& Benner 1994), is probably due to the grazing pressure of flagellates on bacteria and/or virus mortality which leads to an underestimation of the true bacterial biomass produced during the incubation experiments. Protozoans might have partly decomposed the particles studied. This would decrease the BGE values. Changes in the ratios (viable/total bacteria) which were already reported for marine samples (Van Wambeke \& Bianchi 1990), may introduce bias in the calculation of BGE when calculated from abundance. At the beginning of the experiment (within ca 2 to $3 \mathrm{~d}$ ), BGE ranged from 3 to $31 \%$, which is similar to published values (Bjornsen
1986, Tranvik 1988: 20 to 30\%, Turley \& Lochte 1990: 5 to $80 \%$, Smith et al. 1995: 9 to $17 \%$ ). This study indicates that within the first $3 \mathrm{~d}$, the organic carbon is utilized rapidly but with low efficiency, resulting in low biomass production and high microbial respiration, i.e. high $\mathrm{CO}_{2}$ production.

\section{Degradation rates of $\mathrm{TOC}$}

Multi-stage patterns of organic carbon decomposition have already been observed for POC (Westrich \& Berner 1984, Turley \& Lochte 1990, Harvey et al. 1995 , Harvey \& Macko 1997), for DOC (Kirchman et al. 1991, Amon \& Benner 1994, Cherrier et al. 1996, Chen \& Wangersky 1996) and for TOC in marine sediments (Rabouille et al. 1998). In our study, first-order TOC decay constants of $G_{01}$ range from 2.16 to $6.13 \mathrm{~d}^{-1}$ whereas those of $G_{02}$ range from 0.0074 to $0.31 \mathrm{~d}^{-1}$ (Table 3). As we approximated the salp decomposition by a $1 \mathrm{G}$-model, there was only 1 rate $\left(k_{\mathrm{TOC}}=1.60 \mathrm{~d}^{-1}\right)$, the $G_{N R}$ being very small ( $20 \%$ of the initial TOC).

The rates we found in this study were generally higher to those found for marine DOC in numerous studies. Previously reported degradation rates show values ranging from 0.038 to $0.50 \mathrm{~d}^{-1}$ for the first days of DOC degradation in seawater and ranging from 0.001 to $0.048 \mathrm{~d}^{-1}$ for the following days (Kirchman et al. 1991, Amon \& Benner 1994, Cherrier et al. 1996, Chen \& Wangersky 1996). However, it is difficult to compare the previous figures with our own data, since they were not calculated by a $2 \mathrm{G}$-model. In the $2 \mathrm{G}$ model organic carbon is treated as having multiple components with different decay constants acting together during the incubation time. Similarly, the degradation rates reported for phytoplankton-C during 3 mo incubations ranged from 0.035 to $0.041 \mathrm{~d}^{-1}$ (Harvey et al. 1995). However, these authors calculated the rates as the slopes of the logarithm of concentrations against time; therefore we cannot compare our data obtained from the 2G-model. However, if our rates were calculated in a similar manner to Harvey et al. (1995) they would range from 0.089 to $0.75 \mathrm{~d}^{-1}$ for the first days and from 0.002 to $0.06 \mathrm{~d}^{-1}$ thereafter indicating a general agreement with the literature. Although Westrich \& Berner (1984) used a 2G-model, their results were obtained for a much larger period of incubation time (ca $2 \mathrm{yr}$ ) and therefore it is difficult to compare their data with our own. Basically, comparison of labile fractions and degradation rates is difficult to establish without considering incubation times and methods of calculation (Sempéré et al. 1997).

Interestingly, we found that our $k_{2}$ (Table 3) were close to $k_{1}$ 2G-model coefficients $\left(0.038\right.$ and $\left.0.045 \mathrm{~d}^{-1}\right)$ determined by Rabouille et al. (1998) for organic 
carbon in marine sediments. Because organic material deposited on the sediment is likely to be partly degraded, the less labile fraction of surface-water column particles may correspond roughly to the labile fraction found in the sediment. We found that during the second stages only a small quantity ( 2 to $17 \%$ ) of TOC was slowly mineralized ( $k$ ranged from 0.002 to $0.016 \mathrm{~d}^{-1}$ ), which might be due to the exhaustion of the labile organic carbon. However, another explanation might be that our static system (bottles) became limiting in either the diversity of the microbial consortia or in an individual nutrient (Harvey et al. 1995). This would lead to an underestimation of the degradation rates of the less labile and refractory fractions. However, it should be noted that although the sampling area was different, the less labile part of ISP-50 m particles exhibits degradation characteristics $\left(k_{2}=0.016\right.$; $G_{02}=17 \%$ ) close to the labile fraction of the ISP- $200 \mathrm{~m}$ particles $\left(k_{1}=0,089 \mathrm{~d}^{-1}{ }_{i} G_{01}=16 \%\right)$, giving confidence to our experimental protocol for short time (days) incubation experiments.

\section{POC flux in the water column at the Dyfamed Stn 2}

The Dyfamed Stn 2 is far enough from the Ligurian current to be considered representative of biogeochemical processes occurring vertically in the water column in the northwestern Mediterranean Sea (Marty et al. 1994). We are aware that only 1 result taken from experimental work is not enough to extend and explain annual POC flux at this station. However, in a first approach we compared our results (Dyfamed Stn 2) taken from experimental work and subsequent modeling to sediment trap results. At the Dyfamed Stn 2 at $200 \mathrm{~m}$, and assuming a settling velocity of $100 \mathrm{~m} \mathrm{~d}^{-1}$, it would take ca $8 \mathrm{~d}$ for sinking particles to reach $1000 \mathrm{~m}$ depth. According to the 2G-model and the parameters $\left(k_{1}, k_{2} ; G_{01}, G_{02}, G_{\mathrm{NR}}\right)$ obtained for trap particles, $53 \%$ of the $200 \mathrm{~m}$ sinking POC would remain as POC after a microbial decomposition of $8 \mathrm{~d}$. This number is higher than that taken from sediment trap studies, which indicate a POC flux at $1000 \mathrm{~m}$ comprising $35 \%$ of that measured at $200 \mathrm{~m}$ (Miquel et al. 1994). However, it is important to note that POC obtained from our experimental work and 2G-model, includes sinking POC but also suspended POC. As most of the suspended POC is not collected by sediment traps, the difference between the 2 estimates might be due to the release of suspended POC from sinking POC, which accumulates between 200 and $1000 \mathrm{~m}$. Note that loss of POC by mesozooplankton, nekton grazers (Lampitt et al. 1993) and protozoans (Patterson et al. 1993) are not taken into account in the 2G-model and likely contribute to decrease the POC flux. Additionally, confinement effect in our biodegradation experiments could lead to nutrient limitation which is absent during the settling of particles in the water column. This may explain some discrepancies between experimental work and in situ observations based on sediment traps.

Although this model may probably provide acceptable estimates of microbial contribution to the particle decomposition such as $\mathrm{CO}_{2}$, DOC production and bacterial carbon demand, an accurate model of the fates of large particles along the water column needs to be constrained by additional parameters such as suspended POC and DOC releases from sinking POC.

Acknowledgements. We are grateful to Drs Armand Bianchi, Micheline Bianchi, Serge Heussner, Madeleine Goutx and Ingrid Obernosterer for comments on the manuscript, Paul Wassmann for helpful discussions, Christophe Rabouille for help in the calculation of the 2G-model parameters, and Jean Louis Blazy for assistance during analyses. We are grateful to Dr Gaby Gorsky for providing salp bodies and facilities in Villefranche-sur-mer laboratory. Our thanks to the captains and crews of RVs 'Tethys II', 'Suroît' and 'Professeur George Petit' for excellent service at sea. This research has been undertaken in the framework of the Mediterranean Target Project (MTP), EMPS and Euromarge projects and within French-JGOFS-Dynaproc program. We acknowledge the support from the European Commission's Marine Science and Technology (MAST) Program under contract MAS2-CT940090. This work was partly supported by a PhD scholarship provided from the French-CNRS and Ivory Coast government to S.C.Y.

\section{LITERATURE CITED}

Amon RMW, Benner R (1994) Rapid cycling of high-molecular-weight dissolved organic matter in the ocean. Nature 369:549-552

Asper VL, Deuser WG, Knauer GA, Lohrenz SE (1992) Rapid coupling of sinking particle fluxes between surface and deep ocean waters. Nature 357:670-672

Becquevort S, Rousseau V, Lancelot C (1998) Major and comparable roles for free-living and attached bacteria in the degradation of Phaeocystis-derived organic matter in Belgian coastal waters of the North Sea. Aquat Microb Ecol 14:39-48

Berner R (1980) Early diagenesis: a theoretical approach. Princeton University Press, Princeton

Bianchi M, Bonin P, Gorsky G, Christen R, Pouliceck M, Hofle M, Iriberri J, Turley C, Prosser J, Herndl G (1997) European microbiology of particulate systems. In: Lipiatou $E$ (ed) Interdisciplinary research in the Mediterianean Sea. A synthesis of scientific results from the Mediterranean targeted project (MTP) Phase 1 1993-96. Research in enclosed seas, Series 1. Office for official publications of the European Communities, Brugge, p 221-252

Biddanda BA, Pomeroy LR (1988) Microbial aggregation and degradation of phytoplankton-derived detritus in seawater. I. Microbial succession. Mar Ecol Prog Ser 42:79-88

Bjornsen PK (1986) Bacterioplankton growth yield in continuous seawater cultures. Mar Ecol Prog Ser 30:191-196

Chen W, Wangersky P (1996) Rates of microbial degradation 
of dissolved organic carbon from phytoplankton cultures. J Plankton Res 18:1521-1533

Cherrier J, Bauer JE, Druffel ERM (1996) Utilization and turnover of labile dissolved organic matter by bacterial heterotrophs in eastern North surface waters. Mar Ecol Prog Ser 139:267-279

Cho BC, Azam F (1988) Major role of bacteria in biogeochernical fluxes in the ocean's interior. Nature 332:441-443

Christaki U, Van Wambeke F (1995) Simulated phytoplankton bloom input in top-down manipulated microcosms: comparative effect of zooflagellates, ciliates and copepods. Aquat Microb Ecol 9:137-147

Christaki U, Van Wambeke F, Christou ED, Conan P, Gaudy R (1996) Food web structure variability in the surface layer, at a fixed station influenced by the northwestern Mediterranean Current. Hydrobiologia 321:145-153

Copin-Montégut G, Avril B (1993) Vertical distribution and temporal variation of dissolved organic carbon in the north-western Mediterranean sea. Deep-Sea Res 40: 1963-1972

Ducklow HW, Carlson CA (1992) Oceanic bacterial production. In: Marshall KC (ed) Advances in microbial ecology, Vol 12. Plenum Press, New York, p 113-181

Fowler S, Knauer G (1986) Role of large particles in the transport of elements and organic compounds through the oceanic water column. Prog Oceanogr 16:47-194

Fuhrman JA, Azam F (1980) Bacterioplankton secondary production estimates for coastal waters of British Columbia, Antarctica, and California. Appl Environ Microbiol 39: 1085-1095

Gardner WD, Hinga KR, Marra J (1983) Observations on the degradation of biogenic material in the deep ocean with implications on the accuracy of sediment trap fluxes. J Mar Res 41:195-214

Goldman JC (1984) Oceanic nutrient cycles. In: Fasham MJR (ed) Flows of energy and materials and ecosystems. Plenum Press, New York, p 137-169

Harvey HR, Macko SA (1997) Kinetics of phytoplankton decay during simulated sedimentation: changes in lipids under oxic and anoxic conditions. Org Geochem 27: $129-140$

Harvey HR, Tuttle J, Bell J (1995) Kinetics of phytoplankton decay during simulated sedimentation: changes in biochemical composition and microbial activity under oxic and anoxic conditions. Geochim Cosmochim Acta 59: $3367-3377$

Henrich S, Doyle A (1986) Decomposition of 14-C labeled organic substances in marine sediments. Limnol Oceanogr 31:765-778

Herndl GJ (1988) Ecology of amorphous aggregations (marine snow) in the northern Adriatic Sea: II. Microbial density and activity in marine snow and its implication to overall pelagic processes. Mar Ecol Prog Ser 48:265-275

Hoppe HG, Ducklow H, Karrash B (1993) Evidence for dependency of bacterial growth on enzymatic hydrolysis of particulate organic matter in the mesopelagic ocean. Mar Ecol Prog Ser 93:277-283

Jumars PA , Penry DL, Baross JA, Perry MJ, Frost B (1989) Closing the microbial loop: dissolved organic pathway to heterotrophic bacteria from incomplete ingestion, digestion and absorption in animals. Deep-Sea Res 36:483-495

Karl DM, Knauer GA, John MH (1988) Downward flux of particulate organic matter in the ocean: a particle decomposition paradox. Nature 332:438-440

Karner M, Herndl GJ (1992) Extracellular enzymatic activity and secondary production in free-living and marinesnow-associated bacteria. Mar Biol 113:341-347
Khripounoff A, Crassous P (1994) Particulate material degradation in sediment traps at $2000 \mathrm{~m}$ depth on the Meriadzeck Terrace (Bay of Biscay). Deep-Sea Res 41:821-829

Kirchman DL, Suzuki Y, Garside C, Ducklow HW (1991) Hi'gh turnover rates of dissolved organic carbon during a spring phytoplankton bloom. Nature 352:612-614

Koike I, Hara S, Terauchi K, Kogure K (1990) Role of submicrometer particles in the ocean. Nature 345:242-244

Lampitt RS, Wishner KF, Turley CM, Angel MV (1993) Marine snow studies in the northeast Atlantic: distribution, composition and role as a food source for migrating plankton. Mar Biol 116:689-702

Lawrence SG, Ahmad A, Azam F (1993) Fate of particlebound bacteria ingested by Calanus pacificus. Mar Ecol Prog Ser 97:299-307

Lee C, Cronin C (1982) The vertical flux of particulate organic nitrogen in the sea: decomposition of amino acids in the Peru upwelling area and the equatorial Atlantic. J Mar Res 40:227-251

Lefèvre D, Denis M, Lambert CE, Miquel JC (1996) Is DOC the main source of organic carbon remineralization in the ocean water column. J Mar Syst 7:281-291

McCave IN (1984) Size spectra and aggregation of suspended particles in the deep ocean. Deep-Sea Res 31:329-352

Martin JH, Knauer DM, Karl DM , Broenkow WW (1987) VERTEX: carbon cycling in the northeast Pacific. DeepSea Res 34:267-285

Marty JC, Nicolas E, Miquel JC, Fowler SW (1994) Particulate fluxes of organic compounds and their relationships to zooplankton faecal pellets in the northwestern Mediterranean Sea. Mar Chem 46:387-405

Minas HJ (1970) La distribution de l'oxygène en relation avec la production primaire en Méditerranée nord-occidentale. Mar Biol 7:181-204

Minas HJ, Minas M, Coste B, Gostan J, Nival P, Bonin MC (1988) Production de base et de recyclage; une revue de la problématique en Méditerranée Nord occidentale. Oceanol Acta 9:155-162

Miquel JC, Fowler S, La Rosa J, Buat-Menard P (1994) Dynamics of downward flux of particles and carbon in the open northwestern Mediterranean Sea. Deep-Sea Res 41: $243-261$

Moran S, Buesseler K (1992) Short residence time of colloids in the upper ocean estimated from 238U-234Th desequilibria. Nature 356:221-223

Newell R, Lucas MI, Linley EAS (1981) Rate of degradation and efficiency of conversion of phytoplankton debris by marine micro-organisms. Mar Ecol Prog Ser 6:123-136

Nguyen R, Harvey HR (1997) Protein and amino acid cycling during phytoplankton decomposition in oxic and anoxic waters. Org Geochem 27:115-128

Passow U, Wassmann P (1994) On the trophic fate of Phaeocystis pouchetti (Hariot): IV. The formation of marine snow by P. pouchetti. Mar Ecol Prog Ser 104:153-161

Patterson DJ, Nygaard K, Steinberg G, Turley CM (1993) Heterotrophic flagellates and other protists associated with oceanic detritus throughout the water column in the mid North Atlantic. J Mar Biol Assoc UK 73:67-95

Porter KG, Feig YS (1980) The use of DAPI for identifying and counting aquatic microflora. Limnol Oceanogr 25:943-948

Rabouille C, Gaillard JF, Relexans JC, Treguer P, Vincendeau MA (1998) Recycling of organic matter in Antarctic sediments: a transect through the polar front in the southern Ocean (Indian Sector). Limnol Oceanogr 43:420-432

Sempéré R, Cauwet G (1995) Occurrence of organic colloids in the stratified estuary of the Krka River (Croatia). Estuar Coast Shelf Sci 40:105-114 
Sempéré R, Cauwet G, Randon J (1994) Ultrafiltration of seawater with a zirconium and aluminum oxide tubular membrane: application to the study of colloidal organic carbon distribution in an estuarine bottom nepheloid layer. Mar Chem 46:49-60

Sempéré $R$, Van Wambeke $F$, Azourmanian $H$, Chambaud $A L$, Ferrière L, Bianchi M (1997) On the use of batch systems to determine DOC bacterial lability and bacterial growth efficiency in seawater samples. In: Dehairs $F$, Elskens ML, Goeyens L (eds) Integrated marine system analysis. VUB, Brussels, p 223-238

Sempéré $R$, Charrière $B$, Van Wambeke $F$, Cauwet $C$ (in press) Rhône River inputs to the Mediterranean Sea: biogeochemical implications. Global Biogeochem Cycles

Shaffer G (1996) Biogeochemical cycling in the global ocean. 2. New production, Redfield ratios, and remineralization in the organic pump. J Geophys Res 101:3723-3735

Silver MW, Coale SL, Pilskaln CH, Steinberg DR (1998) Giant aggregates: importance as microbial centers and agents of material flux in the mesopelagic zone. Limnol Oceanogr 43:498-507

Simon M, Azam F (1989) Protein content and protein synthesis rates of planktonic marine bacteria. Mar Ecol Prog Ser 51:201-213

Simon M, Alldredge AL, Azam F (1990) Bacterial carbon dynamics on marine snow. Mar Ecol Prog Ser 65:205-211

Smith DC, Sinon M, Alldredge A, Azam F (1992) Intense hydrolytic enzyme activity on marine aggregates and implications for rapid particles dissolution. Nature 359: 139-142

Smith DC, Steward GF, Long RA, Azam F (1995) Bacterial mediation of carbon fluxes during a diatom bloom in a mesocosm. Deep-Sea Res II 42:75-97

Tan FC, Strain PM (1979) Carbon isotope ratios of particulate organic matter in the Gulf of St. Lawrence. J Fish Res Board Can 36:678-682

Tranvik (1988) Availability of dissolved organic carbon for planktonic bacteria in oligotrophic lakes of different humic content. Microb Ecol 16:311-322

Turley CM, Hughes D (1992) Effects of storage on direct estimates of bacterial numbers of preserved seawater samples. Deep-Sea Res 39:375-394

Turley CM, Lochte K (1990) Microbial response to the input of

Editorial responsibility: Otto Kinne (Editor),

Oldendorf/Luhe, Germany fresh detritus to the deep-sea bed. Palaeogeogr Palaeoclimatol Palaeoecol (Global and Planetary Change Section) 89:3-23

Turley CM, Mackie PJ (1994) Biogeochemical significance of attached and free-living bacteria and the flux of particles in the NE Atlantic Ocean. Mar Ecol Prog Ser 115:191-203

Van der Loeff RM, Friedrich J, Bathmann U (1997) Carbon export during the spring bloom at the Antarctica Polar Front determined with the natural tracer 234Th. Deep-Sea Res II 44:457-478

Van Wambeke F (1995) Fate of Phaeodactylum tricornutum and nitrogen flow in an experimental microbial food web limited at the top by protozoans. Aquat Microb Ecol 9: $127-136$

Van Wambeke F, Bianchi M (1990) Effect of organic nitrogen enrichments on marine planktonic networks and heterotophic bacterial potential. Mar Ecol Prog Ser 63:17-25

Walsh I, Dymond J, Collier R (1988) Rates of recycling of biogenic components of settling particles in the ocean derived from sediment trap experiments. Deep-Sea Res 35:43-58

Wells ML, Goldberg ED (1993) Colloid aggregation in seawater. Mar Chem 41:352-358

Westrich J, Berner R (1984) The role of sedimentary organic matter in bacterial sulphate reduction: the $G$ model tested. Limnol Oceanogr 29:236-249

Williams PJleB (1990) The importance of losses during microbial growth: commentary on the physiology, measurement and ecology of the release of dissolved organic material. Mar Microb Food Webs 4:175-206

Yamasaki A, Fukuda $H$, Fukuda R, Miyajima T, Nagata T, Ogawa H, Koike I (1998) Submicrometer particles in northwest Pacific coastal environments: abundance, size distribution, and biological origins. Limnol Océánogr 43: $536-542$

Yoro SC, Sempéré R, Turley CM, Unanue MA, dẻ Madron $\mathrm{XD}$, Bianchi M (1997) Cross-slope variations of organic carbon and bacteria in the Gulf of Lions in relation to water dynamics (northwestern Mediterranean). Mar Ecol Prog Ser 161:255-264

Yoro SC, Panagiotopoulos C, Sempéré R (1999) Dissolved organic carbon contamination induced by filters and storage bottles. Water Res 33:1956-1959

Submitted: August 10, 1999; Accepted: December 13, 1999 Proofs received from author(s): May 15, 2000 